\title{
Fast high-pressure tanning of animal skins by accelerated chromium sulphate complexation
}

\author{
M. Prokein ${ }^{1}\left(\mathbb{D} \cdot\right.$ M. Renner $^{1} \cdot$ E. Weidner ${ }^{1,2}$
}

Received: 3 March 2020 / Accepted: 25 April 2020 / Published online: 5 May 2020

(c) The Author(s) 2020

\begin{abstract}
In the conventional leather production process, basic chromium sulphate (BCS) penetrates fully inside the collagen matrix during tanning and forms oligo-nuclear complexes that stabilize the skin structure during basification. Accelerated chromium sulphate complexation by basifying the BCS before full penetration leads to surface tanning and low leather qualities. Therefore, long processing times of $16 \mathrm{~h}$ for tanning and basification are common in modern tanneries. We used sodium hydrogen carbonate to basify BCS before penetration. However, instead of conventional tanning we performed $\mathrm{CO}_{2}$ tanning at 30 bar. The influence of accelerated chromium sulphate complexation on the leather quality was investigated. To estimate the structures of the formed chromium complexes, we considered the $\mathrm{pH}$ trend of the tanning solution during basification depending on the amount of basifying agent. The distribution of chromium oxide $\left(\mathrm{Cr}_{2} \mathrm{O}_{3}\right)$ and the shrinkage temperature $\left(T_{\mathrm{s}}\right)$ in three different layers of the cross section were analysed. The analytics allowed the assessment whether the tanning agent penetrates through the whole cross section or adheres to the surface during $\mathrm{CO}_{2}$ tanning. We show that $\mathrm{CO}_{2}$-intensified tanning allows accelerated chromium sulphate complexation and a reduction in the tanning time from 16 to $4 \mathrm{~h}$. $\mathrm{The} \mathrm{Cr}_{2} \mathrm{O}_{3}$ is equally distributed, and $T_{\mathrm{s}}$ above $100{ }^{\circ} \mathrm{C}$ meets the standards of high-quality wet blue. However, the $\mathrm{pH}$ value of the tanning solution must not rise above 4.5 during basification. Otherwise, the $T_{\mathrm{s}}$ decrease dramatically. The feasibility of the process is demonstrated in a 1700-L drum, with a batch size of about $500 \mathrm{~kg}$. The $\mathrm{CO}_{2}$-intensified tanning process has high potential to save time and chemicals and reduce emissions in industrial applications and is commercially competitive.
\end{abstract}

\section{Graphic abstract}

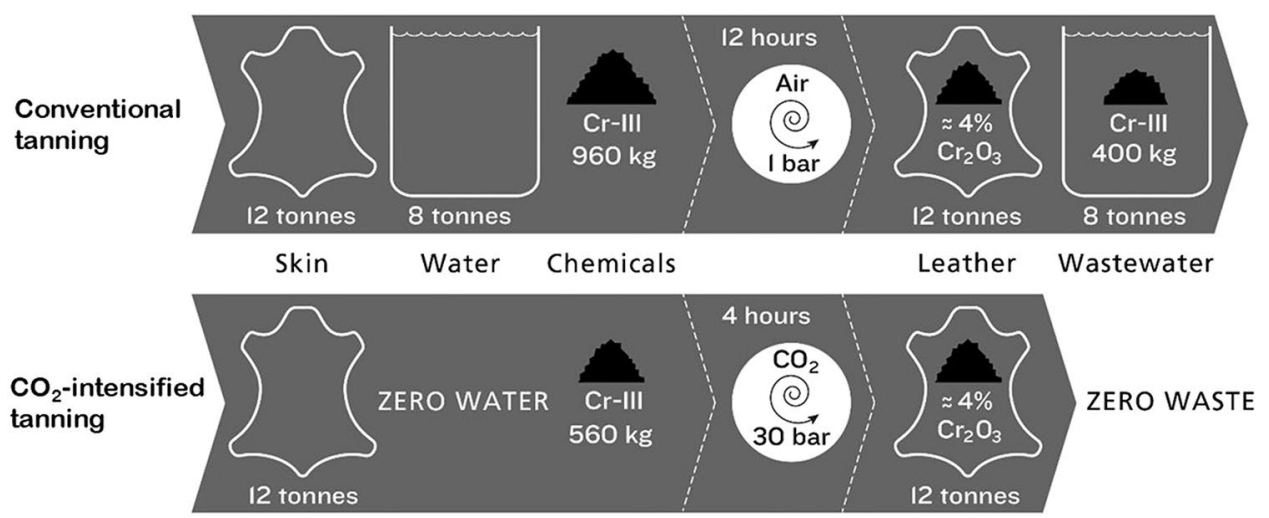

Keywords $\mathrm{CO}_{2} \cdot$ High pressure $\cdot$ Tanning $\cdot$ Basic chromium sulphate $\cdot$ Leather

M. Prokein

michael.prokein@umsicht.fraunhofer.de

Extended author information available on the last page of the article 


\section{State of the art}

\section{Conventional tanning}

The production of chromium leather is comparatively simple and results in high leather qualities. Therefore, more than $85 \%$ of all leathers are chromium-tanned (Covington 2009). The most common tanning agent is basic chromium sulphate (BCS) with a basicity of 33\% (Buljan et al. 2000). In contrast to the advantages of simple processing and high qualities, the production of leather is connected to high water consumptions, poor chemical exhaustions, long operating times and environmental pollution or enormous costs for wastewater treatment (Rydin 2011; Umweltbundesamt 2003). The development of technologies that overcome the disadvantages of conventional tanning is of high importance to allow the economical production of environmentally friendly high-quality leather (Sivakumar et al. 2005; Sundar et al. 2013; Trommer and Kellert 1998).

The pre-tanning processes for the production of chromium leather include soaking, unhairing, deliming, bating and pickling. These processes remove unwanted skin components as hair, fats or non-collagen proteins and acidify the remaining collagen to a $\mathrm{pH}$ value of 3 (Zissel 1988). At $\mathrm{pH} 3$, the majority of the functional carboxy groups of the collagen are protonated and thereby not reactive towards the tanning agent. The low reactivity between the tanning agent and collagen is beneficial to initiate tanning and basification (Faber 1990).

Chromium tanning and basification are the most important steps in the leather production chain. The working steps are performed successively in a rotating drum with an excess of water and tanning agent. The chromium tanning agent penetrates inside the collagen matrix during tanning and cross-links single fibrils during basification.

After dissolving the tanning agent in the pickle solution, BCS forms metal complexes due to deprotonation and olation in the form of chromium-hydroxide-chromium links. Depending on the $\mathrm{pH}$ value, ageing and types of available ligands, many different metal complex structures exist in parallel (Indubala and Ramaswamy 1973; Takenouchi 1981). However, at pH 3 the conditions are not in favour to form oligo-nuclear complexes of sufficient size to cross-link fibrils with a distance of 10 to 16 angstrom between each other (Danylkovych et al. 2017; Imar and Vernali 2000). Consequently, the chromium complexes penetrate fully inside the acidified cross section of the collagen.

In basification, weak alkaline salts increase the $\mathrm{pH}$ value to 3.8 and initiate the formation of more stable $\mu$-hydroxo- $\mu$-sulphato oligo-nuclear complexes by polymerization (Imar and Vernali 2000). In addition, negative charges are introduced to the functional carboxy groups. This increases the reactivity of the chromium complexes towards the collagen. The introduction of two carboxy groups into the same chromium complex results in linking collagen fibrils and stabilizing of the skin structure, leading to fully tanned durable wet blue (Sundar et al. 2002). Linking of chromium complexes by sulphate bridges enables a further stabilization of the skin structure as described by Covington et al. (Covington et al. 2008). The stabilization transforms raw hides and skins into durable wet blue. Wet blue is a worldwide traded intermediate product that is post-processed into leather. The term wet blue derives from its high water content and blue colour caused by the chromium tanning agent (Heidemann 2005).

Essential in the conventional leather production chain is the order of tanning and basification. If basification starts before the complexes have fully penetrated, the tanning agent reacts with the surface of the skin. In this case, a further penetration of the chromium complexes is hindered, resulting in surface tanning and a non-durable wet blue of low quality (Moog 2016).

The detailed operation procedure of chromium tanning process is varying from tannery to tannery. Usually, the tanning agent penetrates fully within 2 to $6 \mathrm{~h}$ depending on the skins thickness. Basification takes a working day (Umweltbundesamt 2003). In total, both working steps require at least $12 \mathrm{~h}$; however, longer operating times of more than $16 \mathrm{~h}$ are typical in modern tanneries to ensure a high leather quality.

\section{$\mathrm{CO}_{2}$-intensified tanning}

The $\mathrm{CO}_{2}$-intensified tanning process combines the positive characteristics of the conventional chromium tanning process like high performance and quality with considerable savings in process time, tanning agent and water, especially wastewater (Renner 2015).

For $\mathrm{CO}_{2}$-intensified tanning, the pretreatment from raw to pickled skin is the same as for conventional tanning. However, in contrast to conventional tanning, the skin leaves the pickle solution after pickling and a press reduces 15 to 30 wt.\% of the initial skin weight by samming. Samming means to press out aqueous solution from the skin by a mechanical press. The sammed skin is contacted with $\mathrm{CO}_{2}$ in a pressureresistant drum. During pressurization, the tanning solution is prepared. For this purpose, basic chromium sulphate and a basifying agent are dissolved in the sammed pickle solution (15 to 30 wt.\% of the initial skin weight). The basification of the tanning solution causes the formation of oligo-nuclear complexes before penetration. A pump forwards the basified solution into the drum against the pressure. The sammed skin absorbs the tanning solution totally. After $1 \mathrm{~h}, \mathrm{CO}_{2}$ is slowly released from the drum and wet blue is removed. The 
minimum time to achieve a quality comparable to conventionally tanned leather is $2.5 \mathrm{~h}$ (Renner et al. 2012). Since the tanning solution is fully absorbed by the skin, no chromium-contaminated wastewater remains and about $40 \%$ of tanning agent are saved (Prokein et al. 2017).

\section{Research issue}

We have already reported about the influence of the pressure on improved chromium uptake (Renner et al. 2009), the principle of avoiding wastewater (Renner et al. 2012), the saving of chromium tanning agent (Gamse 2016) and the reduction in sulphate emissions (Prokein et al. 2017). In this article, we demonstrate the possibility to change the sequence of tanning and basification in $\mathrm{CO}_{2}$-intensified tanning. The aim is to accelerate the formation of reactive chromium sulphate complexes and the stabilization of the skin structure.

To achieve this, we identified

- an optimal ratio between the tanning agent (BCS) and the alkali salt $\left(\mathrm{NaHCO}_{3}\right)$ to achieve an equal distribution of the tanning agent in the cross section, and

- a pH value of about 3.8 and

- a high degree of collagen stabilization comparable to conventionally tanned wet blue.

The role of $\mathrm{pH}$ modification during the preparation of the tanning solution on the formation and structures of oligonuclear complexes depending on the amount of basifying agent is investigated. The complex structures affect the penetration and the stabilization of the collagen structure dramatically (section "Conventional tanning").

In addition, we considered the influence of the degree of samming. Since the degree of samming and at the same time the amount of available liquid for the preparation of the tanning solution vary because of deviating pressing forces of industrial presses, we investigated how different concentrations of $\mathrm{BCS}$ and $\mathrm{NaHCO}_{3}$ are affecting the quality of wet blue.

Based on technical-scale trials, we considered the influence of the amount of tanning agent in pilot scale. The aim was to test the flexibility of the process for industrial applications that demand different concentrations of chromium in the leather for various applications.

\section{Materials and methods}

\section{Materials}

All chemicals employed in the tanning operations were those normally used in the leather industry. "Lanxess
Deutschland GmbH" supplied BCS with a basicity of $33 \%$ (Chromosal B). A basicity of 33\% means the ratio between the negative charges of the hydroxide ion and the positive charges of the chromium atom that result after dissolution of the tanning agent. Sodium hydrogen carbonate was used as a basifying agent with a purity of $>96$ percentage. In this work, all quantities of chemicals are given in weight percentage (wt.\%) based on the wet skin weight. This calculation is the standard to quantify the use of chemical in the leather industry. For example, the use of $4.5 \mathrm{wt} . \%$ of tanning agent means that $45 \mathrm{~g}$ of tanning agent is used for the tanning of $1 \mathrm{~kg}$ of skin.

"Lederfabrik Josef Heinen GmbH \& Co KG" provided pickled bull skins. In pilot scale, full bull tanning with 10 skins per trial was performed. For the trials in technical scale, DIN A5 samples were taken from the croupon. The croupon is the area of the skin with the most regular structure. A comparable structure between the different samples minimizes the influence of natural deviations of the collagen on the experimental results. The detailed preparation of the skins was already described elsewhere (Prokein et al. 2017).

\section{High-pressure equipment}

The tanning trials were performed in a $20-\mathrm{L}$ and $1700-\mathrm{L}$ drum. The maximum pressure of the $20-\mathrm{L}$ drum is $320 \mathrm{bar}$ and of the $1700-\mathrm{L}$ reactor 280 bar. The maximum temperature of both plants is $80^{\circ} \mathrm{C}$. Each plant has a rotatable basket. In the rotating basket, skin can be tanned similar to industrial procedures. A detailed description including schematic diagrams of both plants can be taken from Prokein et al. (Prokein et al. 2017).

\section{Methods}

\section{Determination of the $\mathrm{pH}$ value of the tanning solution depending on the alkali salt concentration}

To assess the influence of an alkali salt on the $\mathrm{pH}$ value during the preparation of the tanning solution, ten beakers were filled with $30 \mathrm{wt} . \%$ of pickle solution and $4.5 \mathrm{wt} . \%$ of BCS each (typical composition of a tanning solution for $\mathrm{CO}_{2}$-intensified tanning). A laboratory shaker mixed all solutions during the whole measurement. $\mathrm{NaHCO}_{3}$ was added in 0.1 wt. $\%$ steps from 0 to 0.9 wt. $\%$. By this procedure, ten solutions with different $\mathrm{NaHCO}_{3}$ concentrations resulted. The maximum amount of $\mathrm{NaHCO}_{3}$ was set to $0.9 \mathrm{wt} . \%$ because at higher dosages chromium complexes precipitated.

After dissolving $\mathrm{NaHCO}_{3}$ in the acidic aqueous solutions, $\mathrm{CO}_{2}$ was bubbling out. This causes intensive foaming depending on the amount of alkali salt for a maximum duration of $5 \mathrm{~min}$. Due to the foaming, the $\mathrm{pH}$ value was 
measured 5 min after adding the basifying agent with a $\mathrm{pH}$ probe "type 911" from "Knick Elektronische Messgeräte $\mathrm{GmbH}$ und Co. KG". Afterwards, the $\mathrm{pH}$ value was measured in defined intervals over a period of $24 \mathrm{~h}$.

\section{$\mathrm{CO}_{2}$-intensified tanning in technical scale}

To identify the optimal ratio between $\mathrm{BCS}$ and $\mathrm{NaHCO}_{3}$, we performed two test series in technical scale. The optimal ratio results when the following criteria are met:

- an equal distribution of the tanning agent in the cross section

- a pH value between 3.8 and 4

- a high degree of collagen stabilization $\left(T_{\mathrm{s}} \geq 100^{\circ} \mathrm{C}\right)$

In addition, a test series was performed to investigate the influence of the samming degree. Deviating samming degrees must not impair the listed specifications, in order to qualify the process for varying pressing forces of industrial presses.

In all three test series, the standard wastewater-free $\mathrm{CO}_{2}$-intensified procedure as summarized in section " $\mathrm{CO}_{2}$ intensified tanning" and described in detail by Prokein et al. (Prokein et al. 2017) was performed. To ensure that the process time of the high-pressure tanning process was not limiting the quality of wet blue, the duration for each experiment including depressurization was $4 \mathrm{~h}$ instead of the minimum needed time of $2.5 \mathrm{~h}$ for $\mathrm{CO}_{2}$ tanning. The maximum pressure was 30 bar. At the beginning, the temperature was kept constant at $30{ }^{\circ} \mathrm{C}$ for $1 \mathrm{~h}$ and was afterwards raised to $40{ }^{\circ} \mathrm{C}$ with a thermal gradient of $1{ }^{\circ} \mathrm{C}$ per $10 \mathrm{~min}$. The deviations between the experiments from the standard method are described in the following:

Description of technical-scale test series 1 Deviating from the standard procedure, 0.6 to 0.9 wt. $\%$ of $\mathrm{NaHCO}_{3}$ in 0.1 wt.\% steps was added in the tanning solution in the first test series. The samming degree was $30 \mathrm{wt} . \%$, and $4.5 \mathrm{wt} . \%$ of tanning agent was used in each experiment.

Description of technical-scale test series 2 In the second test series, the amount of $\mathrm{NaHCO}_{3}$ was $0.7 \mathrm{wt}$.\%. In contrast to the first test series, $\mathrm{NaHCO}_{3}$ was not added in one-step. The whole amount of alkali salt was divided into 2, 3, 5 and 7 dosages that were added in defined intervals within $35 \mathrm{~min}$ into the tanning solution. The samming degree and amount of tanning agent were not changed.

Description of technical-scale test series 3 To investigate the influence of the samming degree, four trials with samming degrees between 15 and $30 \mathrm{wt} \%$ were performed.
0.7 wt.\% of $\mathrm{NaHCO}_{3}$ was added in 3 dosages in the tanning solution containing $4.5 \mathrm{wt} . \%$ of BCS.

\section{$\mathrm{CO}_{2}$-intensified tanning in preindustrial scale}

The preindustrial-scale trials were performed according to the most promising parameters evaluated in the technicalscale test series. The only difference in the procedure compared with the technical-scale trials was that ten full bull skins per trial were sammed with an industrial press in a professional tannery.

To investigate the distribution of $\mathrm{Cr}_{2} \mathrm{O}_{3}$ in the cross section and the flexibility of the process, we used different amounts of BCS between 3.5 and $5 \mathrm{wt} . \%$. In all experiments, 0.7 wt. $\%$ of $\mathrm{NaHCO}_{3}$ was added to the tanning solution in 3 dosages.

\section{Quality assessment}

Assessing the shrinkage temperature is the most common method used in the leather industry to identify the heat resistance of wet blue. To measure the shrinkage temperature, defined parts of the wet blue samples are punched out and heated in a standardized apparatus. The shrinkage temperature is the temperature at which the samples start to shrink. Additionally to the $T_{\mathrm{s}}$, the quality of the wet blue was assessed by $\mathrm{pH}$ value, chromium oxide content, amount of non-fixed chromium and qualitatively by professional tanners. The detailed procedures for the quality assessment in the technical-scale trials have already been described elsewhere (Prokein et al. 2017).

In addition to our previous work, the distribution of the $\mathrm{Cr}_{2} \mathrm{O}_{3}$ content in the cross section of wet blue produced in pilot scale was assessed by "Forschungsinstitut für Leder und Kunststoffbahnen (FILK) gGmbH (Research Institute for Leather and Polymer Coated Substrates)" according to DIN EN ISO 5398-1. Therefore, wet blue was freeze-dried and split into a top layer, a centre layer and a bottom layer. Additionally to the $\mathrm{Cr}_{2} \mathrm{O}_{3}$ content, the $T_{\mathrm{s}}$ of the three layers was measured by FILK by differential scanning calorimetry.

\section{Results and discussion}

\section{Influence of the basifying agent on the pH value of the tanning solution}

The $\mathrm{pH}$ values of the tanning solutions depending on the amount of basifying agent are measured to conclude on structures of formed chromium complexes that have to penetrate through the cross section in tanning. For the measurements, ten tanning solutions containing $4.5 \mathrm{wt} . \%$ of BCS were prepared and different amounts of alkali salt 
were added as described in section "Determination of the $\mathrm{pH}$ value of the tanning solution depending on the alkali saltconcentration".

Figure 1 shows the $\mathrm{pH}$ value of the tanning solutions with 0 to 0.9 wt.\% of $\mathrm{NaHCO}_{3}$ over a period of $24 \mathrm{~h}$. The $\mathrm{pH}$ values of all tanning solutions show a similar trend. All values decrease and reach a minimum. The decrease in the $\mathrm{pH}$ values is fastest at the beginning of the measurements and slows down until the minimum results are reached. Afterwards, the $\mathrm{pH}$ values slightly increase by about 0.1 until the end of the measurements.

Without adding $\mathrm{NaHCO}_{3}$, the $\mathrm{pH}$ value is slightly above 2 after $5 \mathrm{~min}$ and decreases to 1.7 within the first hour. By increasing the amount of $\mathrm{NaHCO}_{3}$, the $\mathrm{pH}$ value increases. In the considered steps of $0.1 \mathrm{wt} . \%$, the $\mathrm{pH}$ values of the solutions rise by 0.6 to 0.8 at the beginning and 0.1 to 0.2 in the end of the measurements. When a maximum of $0.9 \mathrm{wt} . \%$ is used, the $\mathrm{pH}$ value of the tanning solution is 5.4 after the first measurement and decreases to 3.6 within the first hour and to a minimum of 3.2 after $6 \mathrm{~h}$.

The $\mathrm{pH}$ trends shown in Fig. 1 result from the formation of oligo-nuclear chromium complexes. The mechanism can be explained as follows: After dissolving the tanning agent that consists of basic chromium sulphate and sodium sulphate the dissociated chromium(III)-ion binds ligands. Chromium(III) in aqueous solutions occurs as the hydrated hexaaquachromium ion, $\mathrm{Cr}\left(\mathrm{H}_{2} \mathrm{O}\right)_{6}^{3+}$. If only the hexaaquachromium ion resulted, the dissolved sulphate and hydroxide would remain in the free tanning solution and the hydroxide would lead to an increase in the $\mathrm{pH}$ value. Since the $\mathrm{pH}$ value decreases, it is assumed that water held by the chromium ion is exchanged by the sulphate and hydroxide ion (Danylkovych et al. 2017). Figure 2 shows

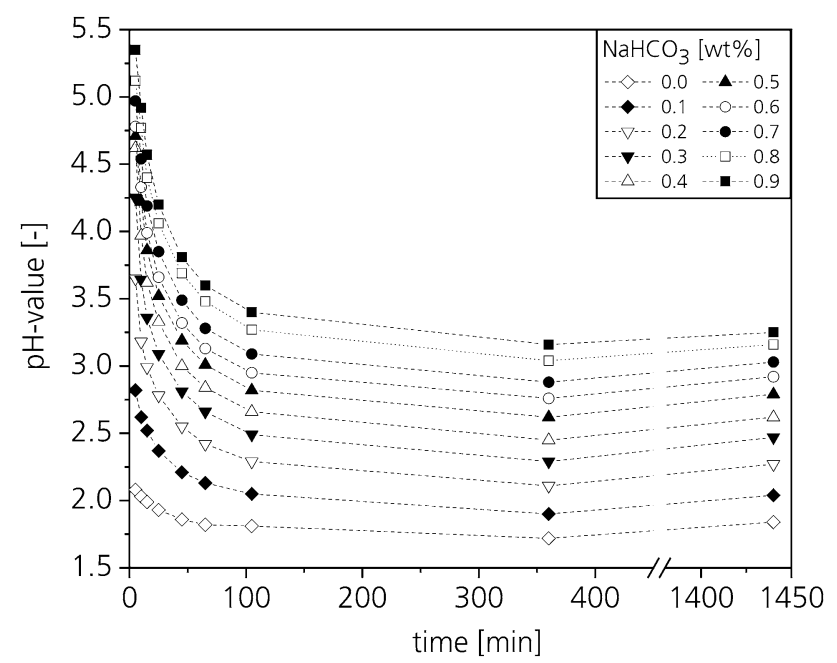

Fig. $1 \mathrm{pH}$ value of a pickle-based tanning solution (samming degree 30 wt.\%) depending on the amount of $\mathrm{NaHCO}_{3}$ from 0 to 0.9 wt. $\%$ and time<smiles></smiles>

Fig. 2 Structure of a hydrated chromium(III) ion in a tanning solution

a possible structure of a hydrated chromium cation that is formed in the tanning solution. However, the formation of the hydrated cation in Fig. 2 does not explain the decrease in the $\mathrm{pH}$ value.

The $\mathrm{pH}$ value of the tanning solution can only decrease when oligo-nuclear complexes are formed and the basicity of the complexes increases above the initial basicity of $33 \%$.

Figure 3 shows a binuclear chromium complex. Since the tanning agent contains a sufficient amount of hydroxide to form the illustrated binuclear complex, the basicity of the complex stays at $33 \%$ and the formation of the complex would not provide protons to the solution to decrease the $\mathrm{pH}$ value. This means, as soon as complexes with more than two chromium atoms are formed, the $\mathrm{pH}$ value of the tanning solution decreases. Figure 4 shows the structure of a tetra-nuclear complex. For the formation of the tetra-nuclear complex, hydroxide ions of the free solution are bonded. The bonding of free hydroxide ions causes the decrease in the $\mathrm{pH}$ value of the aqueous solution and the increase in the basicity of the complex to $50 \%$.

Based on the previous explanations, from Fig. 1 we derive that also without adding alkali salt more than binuclear complexes are formed. Since the tanning agent only consists of chromium sulphate and sodium sulphate, there is no component that could explain the decrease in the $\mathrm{pH}$ value. However, without alkali salt the reactivity of the tanning<smiles>O=S1(=O)OC(O)(O)OS2(=O)(O)OC(O)(O1)OS(=O)(=O)O2</smiles>

Fig. 3 Structure of a binuclear chromium complex with a basicity of $33 \%$ 


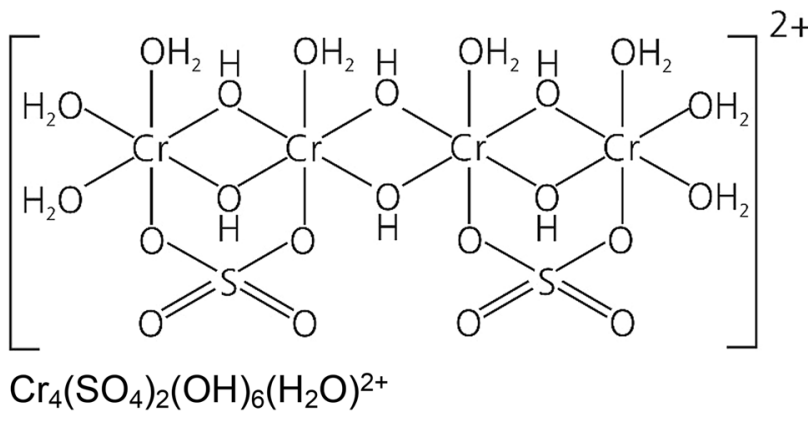

Fig. 4 Structure of a tetra-nuclear chromium complex with a basicity of $50 \%$

agent is too low to stabilize the skin structure (Covington et al. 2008).

After dissolving the alkali salt at the beginning of the experiment, the maximum $\mathrm{pH}$ value is reached. The high $\mathrm{pH}$ value facilitates the deprotonation and at the same time the linking of $\mathrm{Cr}$ atoms by $\mathrm{OH}$ bridges. The fast $\mathrm{pH}$ drop at the beginning of the experiment indicates that the oligomerization of the complexes is faster at higher $\mathrm{pH}$ values and slows down when the $\mathrm{pH}$ value decreases. This is not surprising because the reaction of introducing hydroxide ions in the complex becomes less exothermic by increasing the number of already bonded OH (Imar and Vernali 2000). When more than 0.9 wt.\% is used, precipitates were observed at the beginning of the measurement. This shows that some insoluble octo-nuclear complexes were formed.

The test series explains the challenge to accelerate the formation of oligo-nuclear complexes by basification before the tanning agent penetrated fully in conventional tanning. The size of the chromium complexes would be too large to allow a slow penetration towards the whole cross section. Based on these results, we will clarify in the following sections how the basification of the tanning solution affects the $\mathrm{CO}_{2}$-intensified tanning process.

\section{$\mathrm{CO}_{2}$-intensified tanning in technical scale}

\section{Influence of the ratio between $\mathrm{NaHCO}_{3}$ and $\mathrm{BCS}$}

Our first test series in technical scale was performed to investigate whether the tanning solution can be basified before penetration of BCS into the skins cross section during the $\mathrm{CO}_{2}$-intensified tanning process without impairing the quality of wet blue. A ratio between $\mathrm{NaHCO}_{3}$ and $\mathrm{BCS}$ aims achieving a $\mathrm{pH}$ value of 3.8 comparable to conventional wet blue. Based on the results of the previous test series, 0.5 to 0.9 wt. $\%$ of $\mathrm{NaHCO}_{3}$ was added in one dosage and the $\mathrm{CO}_{2}$-intensified tanning was performed as described in section " $\mathrm{CO}_{2}$-intensified tanning in technical scale".

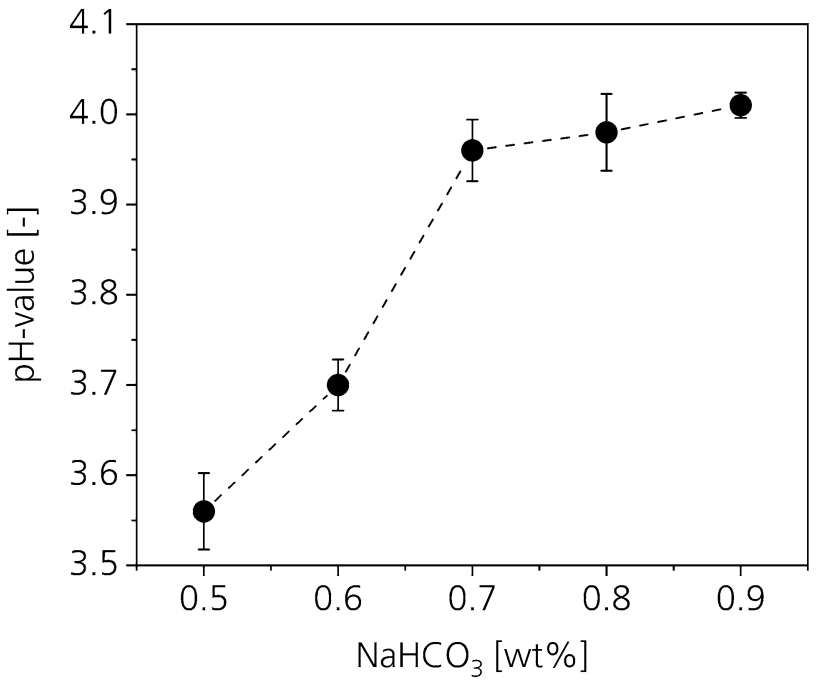

Fig. $5 \mathrm{pH}$ value of wet blue after $\mathrm{CO}_{2}$-intensified tanning depending on the amount of $\mathrm{NaHCO}_{3}$

In all trials, the skins absorbed the tanning solution totally. No free tanning solution was found in the drum after the process. After cutting the tanned skin, no uncoloured area was visible. The tanning agent equally colourized the cross section, indicating full penetration.

Figure 5 shows the $\mathrm{pH}$ values of the wet blue after $\mathrm{CO}_{2}$ tanning depending on different amounts of $\mathrm{NaHCO}_{3}$. By increasing the amount of basifying agent, the $\mathrm{pH}$ value of the wet blue increases. At $0.5 \mathrm{wt} . \%$, a pH value of 3.5 results. At 0.6 wt.\%, the $\mathrm{pH}$ value is 3.7 . A pH value of 3.96 is reached by adding $0.7 \mathrm{wt} . \%$. A further increase in $\mathrm{NaHCO}_{3}$ has a negligible effect on the $\mathrm{pH}$ value compared with the previously observed increase in $\mathrm{pH}$. At 0.8 and $0.9 \mathrm{wt} . \%$, the $\mathrm{pH}$ values are about 4 . The standard deviations are between 0.01 and 0.04 . These deviations are common for tanned wet blue because the functional groups of the collagen and not bonded chromium complexes influence the $\mathrm{pH}$ value of the wet skins even during storing.

The results show that in $\mathrm{CO}_{2}$ tanning a $\mathrm{pH}$ value of 3.8 in combination with full penetration can be achieved by basifying the tanning solution with $\mathrm{NaHCO}_{3}$. The optical assessment of the colorization of the cross section indicates full penetration; however, the distribution of BCS in the cross section that is important for an equal stabilization of the collagen structure is discussed later in this work.

The shrinkage temperatures of the tanned wet blue depending on the amount of alkali salt are shown in Fig. 6 . The highest $T_{\mathrm{s}}$ of $98{ }^{\circ} \mathrm{C}$ with a standard deviation of 1.2 resulted at $0.5 \mathrm{wt} . \%$ of $\mathrm{NaHCO}_{3}$ corresponding to the lowest $\mathrm{pH}$ value of 3.55. By increasing the amount of $\mathrm{NaHCO}_{3}$, the average values of the $T_{\mathrm{s}}$ are between 91 and $93{ }^{\circ} \mathrm{C}$ with standard deviations between 0 and 3.1. 


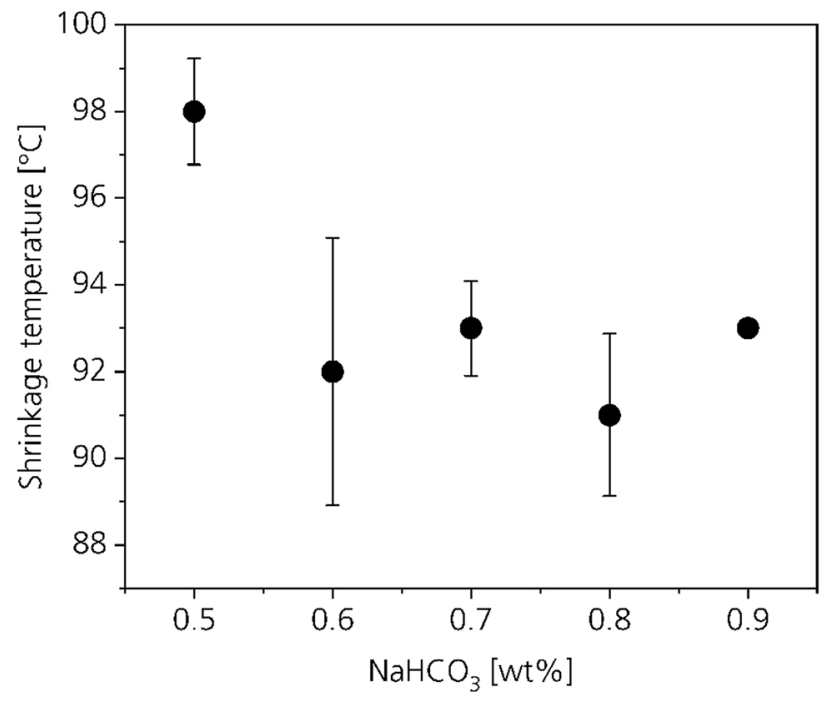

Fig. 6 Shrinkage temperature of wet blue after $\mathrm{CO}_{2}$-intensified tanning depending on the amount of $\mathrm{NaHCO}_{3}$

The $T_{\mathrm{s}}$ of $98^{\circ} \mathrm{C}$ at a pH value of 3.55 is comprehensible. At $\mathrm{pH}$ values above 3.5, the reactivity between BCS and the collagen is already sufficient to reach $T_{\mathrm{s}}$ in the region of $100{ }^{\circ} \mathrm{C}$. However, with respect to the $\mathrm{pH}$ values, the trend of the $T_{\mathrm{s}}$ is surprising. Contrary to the results of this test series, the astringency of the tanning agent towards the collagen and at the same time the $T_{\mathrm{s}}$ increase by increasing the $\mathrm{pH}$ value. We think that in our case the $T_{\mathrm{s}}$ decreases by increasing the $\mathrm{pH}$ value because of the preparation of the tanning solution. In all trials, the alkali salt was added in one step at the beginning of the preparation. This approach generated $\mathrm{pH}$ values above 5 at $\mathrm{NaHCO}_{3}$ applications above $0.5 \mathrm{wt} . \%$. The high $\mathrm{pH}$ values cause the formation of unfavourable chromium complex structures for achieving an equal Cr distribution and stabilization of the collagen matrix leading to lower $T_{\mathrm{s}}$ at higher $\mathrm{pH}$ values.

Figure 7 shows the $\mathrm{Cr}_{2} \mathrm{O}_{3}$ contents of the wet blue that resulted after $\mathrm{CO}_{2}$-intensified tanning with different amounts of $\mathrm{NaHCO}_{3}$. Although the same amount of BCS was used in all trials, the $\mathrm{Cr}_{2} \mathrm{O}_{3}$ contents differ between 2.3 and 3 wt. $\%$. At 0.5 wt. $\%$ of $\mathrm{NaHCO}_{3}$, the $\mathrm{Cr}_{2} \mathrm{O}_{3}$ content reached 2.9 with a standard deviation of 0.1 . A similar value of 3 with a standard deviation of 0.4 was measured at $0.6 \mathrm{wt} . \%$. At 0.7 and 0.8 wt. \%, lower $\mathrm{Cr}_{2} \mathrm{O}_{3}$ contents of 2.4 and 2.3 wt. $\%$ with standard deviations of 0.3 and 0.4 resulted. $\mathrm{The} \mathrm{Cr}_{2} \mathrm{O}_{3}$ content at the highest $\mathrm{NaHCO}_{3}$ application was $2.7 \mathrm{wt} . \%$.

From the results, it is hard to derive a correlation between the $\mathrm{Cr}_{2} \mathrm{O}_{3}$ contents, the shrinkage temperatures and the $\mathrm{pH}$ values. For example, at $0.6 \mathrm{wt} \%$ of $\mathrm{NaHCO}_{3}$ a $\mathrm{pH}$ value of 3.7 resulted in combination with the highest average $\mathrm{Cr}_{2} \mathrm{O}_{3}$ content of $3 \mathrm{wt} . \%$. At these conditions, a shrinkage temperature of about $100{ }^{\circ} \mathrm{C}$ is expected. However, the average

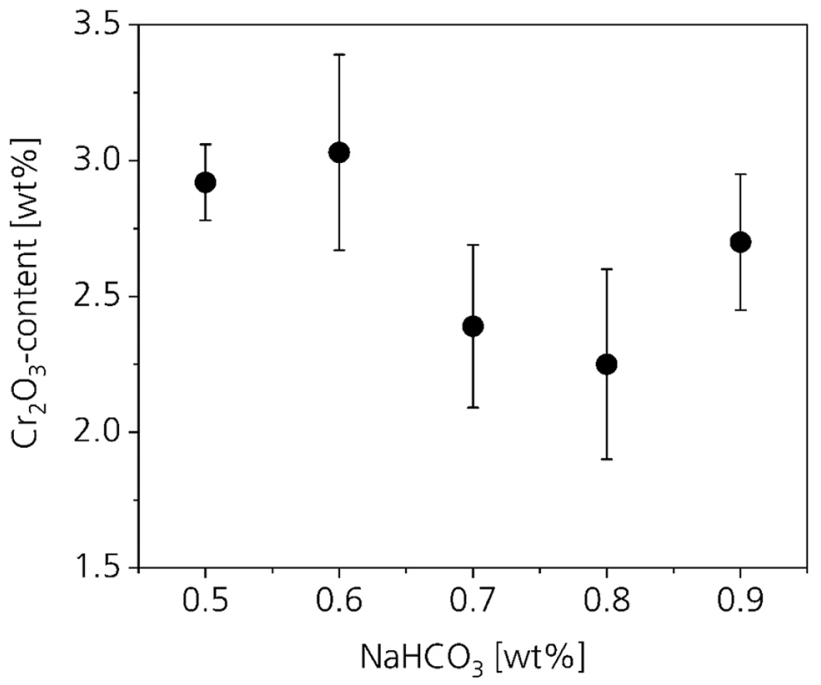

Fig. $7 \mathrm{Cr}_{2} \mathrm{O}_{3}$ content of wet blue after $\mathrm{CO}_{2}$-intensified tanning depending on the amount of $\mathrm{NaHCO}_{3}$

$T_{\mathrm{S}}$ was $8{ }^{\circ} \mathrm{C}$ lower. This observation supports our hypothesis. High $\mathrm{pH}$ values at the beginning of the preparation of the tanning solution cause the formation of unfavourable chromium complex structures and a non-equal $\mathrm{Cr}$ distribution. The hypothesis becomes further underlined by the fact that at the lowest $\mathrm{pH}$ value the lowest standard deviation of the $\mathrm{Cr}_{2} \mathrm{O}_{3}$ content was reached indicating the best $\mathrm{Cr}$ distribution.

Figure 8 shows the unfixed chromium that can be washed out in post-processing. By adding $\mathrm{NaHCO}_{3}$, the $\mathrm{pH}$ value increases and the amount of unfixed chromium decreases from 694 to $225 \mathrm{mg}$ of $\mathrm{Cr}$ per $\mathrm{kg}$ of wet blue. In contrast to the correlation between the $\mathrm{pH}$ and the $T_{\mathrm{s}}$, this result is not

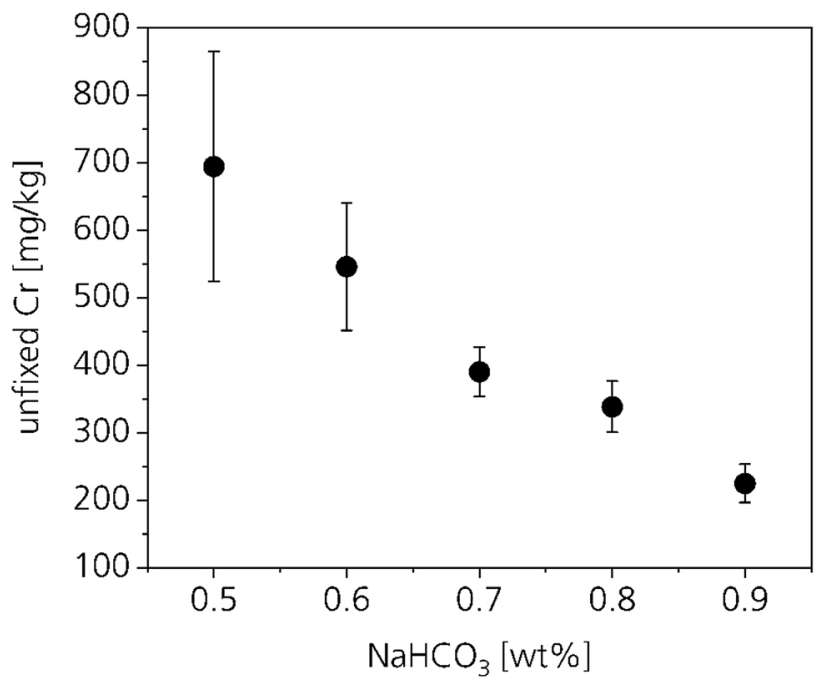

Fig. 8 Unfixed chromium after $\mathrm{CO}_{2}$-intensified tanning depending on the amount of $\mathrm{NaHCO}_{3}$ 
surprising. The affinity of the chromium complexes towards the reactive groups of the collagen increases by increasing the $\mathrm{pH}$ value. That shows that the chromium complexes that penetrate inside the collagen are strongly fixed; however, their structures or distribution is not in favour to achieve an equal stabilization of the skin structure.

\section{Influence of alkali dosages during the preparation of the tanning solution}

To assess the influence of the $\mathrm{pH}$ value at the beginning of the preparation of the tanning solution, the alkali salt was added in various intervals within $35 \mathrm{~min}$. Afterwards, the $\mathrm{CO}_{2}$ tanning process was performed. For all trials, $0.7 \mathrm{wt} . \%$ of $\mathrm{NaHCO}_{3}$ was used. At 0.7 wt. $\%$ of $\mathrm{NaHCO}_{3}$, the aimed $\mathrm{pH}$ value between 3.8 and 4 resulted in the previous test series.

The varying preparation of the tanning solutions resulted in different $\mathrm{pH}$ trends. Table 1 shows the $\mathrm{pH}$ values of the tanning solutions depending on the number of dosages 5 min after the first dosage and at the beginning of the tanning process. By adding the full amount of alkali salt in one step, the $\mathrm{pH}$ value was slightly above 5 after the first measurement and 3.98 after $35 \mathrm{~min}$. This is in good agreement with the $\mathrm{pH}$ trend visualized in Fig. 1. An increased number of dosages lead to decreased $\mathrm{pH}$ values at the beginning of the preparation of the tanning solution and increased $\mathrm{pH}$ values after $35 \mathrm{~min}$. With at least 2 dosages, the $\mathrm{pH}$ values were below 5 during the whole preparation period.

Figure 9 shows the $T_{\mathrm{s}}$ depending on the number of dosages within $35 \mathrm{~min}$. By adding the alkali salt in one step, the $T_{\mathrm{s}}$ reached $93{ }^{\circ} \mathrm{C}$ with a standard deviation of 0.7 . By basifying the tanning solution in two or more steps, the $T_{\mathrm{s}}$ are between 97.3 and $98.5^{\circ} \mathrm{C}$.

The increase in the $T_{\mathrm{s}}$ at more than one dosage results from the reduced $\mathrm{pH}$ values during the preparation of the tanning solution. When the alkali salt is added into the tanning solution in one step, the lowest $\mathrm{pH}$ value at the beginning of the $\mathrm{CO}_{2}$ tanning process results; however, at

Table $1 \mathrm{pH}$ value of tanning solutions depending on the number of alkali dosages within $35 \mathrm{~min}$

\begin{tabular}{llll}
\hline $\begin{array}{l}\text { Number of } \\
\text { dosages within } \\
35 \text { min [-time/s] }\end{array}$ & $\begin{array}{l}\mathrm{NaHCO}_{3} \\
\text { per dos- } \\
\text { age } \\
\text { [g/kg } \\
\text { skin] }\end{array}$ & $\begin{array}{l}\mathrm{pH} \text { value of } \\
\text { tanning solution } \\
\text { after 5 min [-] }\end{array}$ & $\begin{array}{l}\mathrm{pH} \text { value of tan- } \\
\text { ning solution after } \\
35 \text { min [-] }\end{array}$ \\
\hline 1 & 7.0 & 5.0 & \\
2 & 3.5 & 4.4 & 4.0 \\
3 & 2.3 & 3.3 & 4.1 \\
5 & 1.4 & 2.7 & 4.3 \\
7 & 1.0 & 2.4 & 4.4 \\
\hline
\end{tabular}

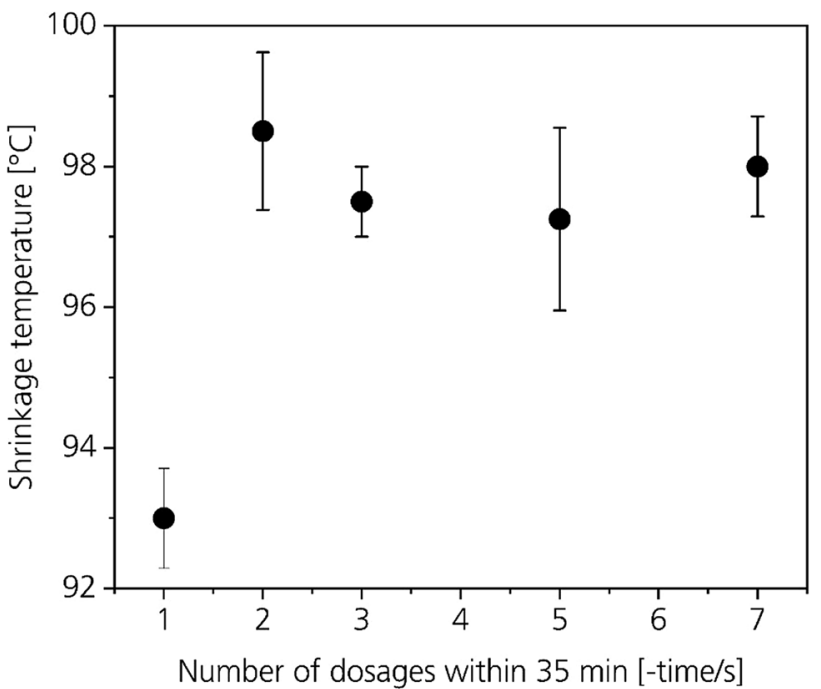

Fig. 9 Shrinkage temperature depending on alkali dosages within $35 \mathrm{~min}$

the beginning of the preparation the highest $\mathrm{pH}$ value of about 5 was measured. The high $\mathrm{pH}$ value at the beginning facilitates the deprotonation and the fast formation of oligonuclear complexes. Dispensing the alkali salt leads to lower $\mathrm{pH}$ values at the beginning of the preparation. At lower $\mathrm{pH}$ values, the olation slows down. This enables the formation of chromium complex structures that achieve a sufficient stabilization of the collagen matrix to reach $T_{\mathrm{s}}$ close to $100{ }^{\circ} \mathrm{C}$.

At dosages between two and seven, all average values are in the standard deviations of all other average values. This shows that avoiding $\mathrm{pH}$ values above 4.5 during the preparation of the tanning solution for the considered ratio between $\mathrm{BCS}$ and $\mathrm{NaHCO}_{3}$ enables the formation of favourable complex structures regarding their tanning efficiency in the high-pressure tanning process.

The $\mathrm{pH}$ values, $\mathrm{Cr}_{2} \mathrm{O}_{3}$ contents and amount of unfixed chromium of all tanned wet blue in all trials were comparable. The $\mathrm{pH}$ values were between 3.74 and 3.85. $\mathrm{The} \mathrm{Cr}_{2} \mathrm{O}_{3}$

Table $2 \mathrm{pH}$ values, $\mathrm{Cr}_{2} \mathrm{O}_{3}$ contents and unfixed chromium depending on alkali dosages

\begin{tabular}{|c|c|c|c|c|c|}
\hline \multirow[t]{2}{*}{$\begin{array}{l}\text { Number of dos- } \\
\text { ages [time/s] }\end{array}$} & \multirow[t]{2}{*}{$\mathrm{pH}$ value $[-]$} & \multicolumn{2}{|c|}{$\begin{array}{l}\mathrm{Cr}_{2} \mathrm{O}_{3} \text { content } \\
\text { [wt.\%] }\end{array}$} & \multicolumn{2}{|c|}{$\begin{array}{l}\text { Unfixed chro- } \\
\text { mium } \\
{[\mathrm{mg} \mathrm{Cr} / \mathrm{kg} \mathrm{skin}]}\end{array}$} \\
\hline & & AV & SD & $\mathrm{AV}$ & $\mathrm{SD}$ \\
\hline 1 & 3.74 & 3.17 & 0.31 & 528 & 54 \\
\hline 2 & 3.82 & 2.83 & 0.22 & 609 & 94 \\
\hline 3 & 3.85 & 2.96 & 0.08 & 565 & 63 \\
\hline 5 & 3.76 & 2.85 & 0.11 & 581 & 74 \\
\hline 7 & 3.84 & 2.78 & 0.32 & 514 & 76 \\
\hline
\end{tabular}


contents were between 2.78 and 3.17. Between 514 and $610 \mathrm{mg}$ of unfixed chromium per $\mathrm{kg}$ of wet blue was washed out. All values are summarized in Table 2. The deviations between all values are comparable with conventionally tanned wet blue and caused by the natural character of the material. We derive that the number of dosages does only influence the shrinkage temperatures due to the formation of different complex structures at varying $\mathrm{pH}$ values.

The required $T_{\mathrm{s}}$ of $100{ }^{\circ} \mathrm{C}$ for high-quality wet blue was not achieved. Reasons for the insufficient $T_{\mathrm{S}}$ can be a too low amount of BCS, an uneven distribution of chromium in the cross section and the low mechanical action caused by the small diameter of the autoclave in technical scale. The possible influences will be considered in section " $\mathrm{CO}_{2}$-intensified tanning in pilot scale".

\section{Influence of samming degree}

The aim of this test series was to investigate the influence of the samming degree corresponding to the available amount of liquid for the tanning solution. In the previous test series, two alkali dosages were sufficient to achieve a high shrinkage temperature. To ensure that unfavourable high $\mathrm{pH}$ values during the preparation of the tanning solution result, three dosages of $\mathrm{NaHCO}_{3}$ were added within $35 \mathrm{~min}$. In comparison with the previous test series, the amount of BCS was increased from 4 to $4.5 \mathrm{wt} . \%$.

Table 3 summarizes the analytical results of the tanned wet blue depending on the samming degree. In all trials, $T_{\mathrm{s}}$ of $100{ }^{\circ} \mathrm{C}$ were reached. This can be explained with the increased amount of BCS compared with the previous test series. The deviations between the $\mathrm{pH}$ values $(3.79$ min to $3.86_{\max }$ ) and $\mathrm{Cr}_{2} \mathrm{O}_{3}$ contents (3.2 wt. $\%_{\text {min }}$ to $3.5 \mathrm{wt} . \%_{\max }$ ) depending on the samming degree are common for conventional wet blue.

The deviations between the amounts of unfixed chromium are higher compared with the other analytical results. At a samming degree of $30 \mathrm{wt} . \%$, the lowest amount of $741 \mathrm{mg}$ Cr per kg of wet blue was washed out. The highest amount of unfixed chromium with $1086 \mathrm{mg} \mathrm{Cr}$ per $\mathrm{kg}$ of wet blue was washed out at a samming degree of $25 \mathrm{wt} . \%$. Since the biggest deviations between the amounts of unfixed chromium resulted between the two highest samming degrees, there is no correlation between the samming degree and the amount of unfixed chromium. We derive that the deviations result from the natural character of the material.

In sum, the amount of the samming degree between 15 and $30 \mathrm{wt} . \%$ and the amount of available pickle solution do not influence the quality of wet blue.

\section{$\mathrm{CO}_{2}$-intensified tanning in pilot scale}

The aim of the pilot-scale trials was to assess the flexibility of the $\mathrm{CO}_{2}$-intensified tanning process regarding different concentrations of tanning agent, the distribution of $\mathrm{Cr}_{2} \mathrm{O}_{3}$ in the cross section and the quality of finished leather process of $\mathrm{CO}_{2}$ tanned wet blue.

After all full bull tanning trials, the tanned skins were equally blue-coloured. The tanning agent penetrated fully. All measured $\mathrm{pH}$ values were between 3.75 and 3.85.

The $T_{\mathrm{s}}$ and the $\mathrm{Cr}_{2} \mathrm{O}_{3}$ contents in the different layers were measured by FILK as described in the " $\mathrm{CO}_{2}$-intensified tanning in preindustrial scale" section. Deviating from the technical-scale trials, the wet blue was freeze-dried and split into a top, centre and bottom layers. Table 4 shows the thicknesses of the different layers.

Table 5 presents the onset and peak temperatures of the evaluated DSC curves depending on the amount of BCS. The average peak temperatures increase from 98.1 to $102.8{ }^{\circ} \mathrm{C}$ by increasing BCS from 3.5 to $4.5 \mathrm{wt} . \%$. Between 4.5 and $5 \mathrm{wt} . \%$, the $T_{\mathrm{s}}$ are constant. At a concentration of $4 \mathrm{wt} . \%$, the peak temperature of $99.8{ }^{\circ} \mathrm{C}$ meets the qualifications of high-quality wet blue.

In all experiments, the $T_{\mathrm{s}}$ in the centre layer are about $1{ }^{\circ} \mathrm{C}$ lower compared to the $T_{\mathrm{s}}$ of the top and the bottom

Table 4 Thicknesses of the wet blue layer after freeze drying and splitting

\begin{tabular}{lllll}
\hline & $\begin{array}{l}\text { BCS } \\
\text { [wt.\%] }\end{array}$ & $\begin{array}{l}\text { Top layer } \\
\text { [mm }]\end{array}$ & $\begin{array}{l}\text { Centre layer } \\
{[\mathrm{mm}]}\end{array}$ & $\begin{array}{l}\text { Bottom layer } \\
\text { [mm }]\end{array}$ \\
\hline Wet blue 1 & 3.5 & 0.80 to 0.95 & 0.70 to 0.90 & 0.70 to 0.95 \\
Wet blue 2 & 4.0 & 0.80 to 0.95 & 0.70 to 0.90 & 1.10 to 1.25 \\
Wet blue 3 & 4.5 & 0.85 to 1.05 & 1.00 to 1.05 & 0.90 to 1.00 \\
Wet blue 4 & 5.0 & 1.20 to 1.20 & 1.05 to 1.25 & 0.90 to 1.10 \\
\hline
\end{tabular}

Table $3 \mathrm{pH}$ values, shrinkage temperatures, $\mathrm{Cr}_{2} \mathrm{O}_{3}$ contents and unfixed chromium of wet blue depending on the samming degree

\begin{tabular}{|c|c|c|c|c|c|c|c|}
\hline \multirow[t]{2}{*}{$\begin{array}{l}\text { Samming } \\
\text { [wt.\%] }\end{array}$} & \multirow[t]{2}{*}{$\begin{array}{l}\mathrm{pH} \\
{[-]}\end{array}$} & \multicolumn{2}{|l|}{$\begin{array}{l}T_{\mathrm{s}} \\
{\left[{ }^{\circ} \mathrm{C}\right]}\end{array}$} & \multicolumn{2}{|c|}{$\begin{array}{l}\mathrm{Cr}_{2} \mathrm{O}_{3} \text { content } \\
\text { [wt.\%] }\end{array}$} & \multicolumn{2}{|c|}{$\begin{array}{l}\text { Unfixed Cr } \\
\text { [mg Cr/kg skin] }\end{array}$} \\
\hline & & AV & SD & AV & $\mathrm{SD}$ & AV & SD \\
\hline 15 & 3.79 & 100 & 0.0 & 3.4 & 0.3 & 946 & 164 \\
\hline 20 & 3.86 & 100 & 0.5 & 3.2 & 0.1 & 854 & 90 \\
\hline 25 & 3.82 & 100 & 0.0 & 3.5 & 0.2 & 1,086 & 135 \\
\hline 30 & 3.86 & 100 & 0.4 & 3.2 & 0.2 & 741 & 71 \\
\hline
\end{tabular}


Table 5 Onset and peak temperatures of the evaluated DSC curves

\begin{tabular}{|c|c|c|c|c|c|}
\hline & Top layer & Centre layer & Bottom layer & $\mathrm{AV}$ & $\mathrm{SD}$ \\
\hline \multicolumn{6}{|l|}{ Wet blue 1} \\
\hline $\begin{array}{l}\text { Onset tempera- } \\
\text { ture }\left[{ }^{\circ} \mathrm{C}\right]\end{array}$ & 96.8 & 95.3 & 95.4 & 95.8 & 0.8 \\
\hline $\begin{array}{l}\text { Peak tempera- } \\
\text { ture }\left[{ }^{\circ} \mathrm{C}\right]\end{array}$ & 98.4 & 97.4 & 98.4 & 98.1 & 0.6 \\
\hline \multicolumn{6}{|l|}{ Wet blue 2} \\
\hline $\begin{array}{l}\text { Onset tempera- } \\
\text { ture }\left[{ }^{\circ} \mathrm{C}\right]\end{array}$ & 99.4 & 97.3 & 97.2 & 98.0 & 1.2 \\
\hline $\begin{array}{l}\text { Peak tempera- } \\
\text { ture }\left[{ }^{\circ} \mathrm{C}\right]\end{array}$ & 101.1 & 98.7 & 99.5 & 99.8 & 1.2 \\
\hline \multicolumn{6}{|l|}{ Wet blue 3} \\
\hline $\begin{array}{l}\text { Onset tempera- } \\
\text { ture }\left[{ }^{\circ} \mathrm{C}\right]\end{array}$ & 101.1 & 100.2 & 100.8 & 100.7 & 0.5 \\
\hline $\begin{array}{l}\text { Peak tempera- } \\
\text { ture }\left[{ }^{\circ} \mathrm{C}\right]\end{array}$ & 102.9 & 102.5 & 102.9 & 102.8 & 0.2 \\
\hline \multicolumn{6}{|l|}{ Wet blue 4} \\
\hline $\begin{array}{l}\text { Onset tempera- } \\
\text { ture }\left[{ }^{\circ} \mathrm{C}\right]\end{array}$ & 100.3 & 99.1 & 100.5 & 100.0 & 0.8 \\
\hline $\begin{array}{l}\text { Peak tempera- } \\
\text { ture }\left[{ }^{\circ} \mathrm{C}\right]\end{array}$ & 102.3 & 101.7 & 103.0 & 102.4 & 0.9 \\
\hline
\end{tabular}

Table 6 Results of the chromium oxide content determinations depending on the amount of BCS

\begin{tabular}{|c|c|c|c|c|c|}
\hline & Top layer & Centre layer & Bottom layer & AV & SD \\
\hline \multicolumn{6}{|l|}{ Wet blue 1} \\
\hline $\begin{array}{l}\mathrm{Cr}_{2} \mathrm{O}_{3} \text { content } \\
{[\mathrm{wt} . \%]}\end{array}$ & 2.90 & 2.75 & 2.80 & 2.8 & 0.1 \\
\hline \multicolumn{6}{|l|}{ Wet blue 2} \\
\hline $\begin{array}{l}\mathrm{Cr}_{2} \mathrm{O}_{3} \text { content } \\
\text { [wt.\%] }\end{array}$ & 3.25 & 3.35 & 3.40 & 3.3 & 0.1 \\
\hline \multicolumn{6}{|l|}{ Wet blue 3} \\
\hline $\begin{array}{l}\mathrm{Cr}_{2} \mathrm{O}_{3} \text { content } \\
{[\text { wt.\%] }}\end{array}$ & 4.5 & 4.45 & 4.55 & 4.5 & 0.1 \\
\hline \multicolumn{6}{|l|}{ Wet blue 4} \\
\hline $\begin{array}{c}\mathrm{Cr}_{2} \mathrm{O}_{3} \text { content } \\
\text { [wt.\%] }\end{array}$ & 4.6 & 4.6 & 4.6 & 4.6 & 0 \\
\hline
\end{tabular}

layer. Before BCS reaches the centre layer, it has to diffuse through the top or bottom layer. Thus, slightly lower concentrations of BCS in the centre layer leading to a decreased stabilization of the skin structure linked to lower $T_{\mathrm{s}}$ are not surprising. However, a deviation of $1{ }^{\circ} \mathrm{C}$ between the temperatures of the centre and the other layers is low. In general, all standard deviations are negligible having a maximum value of 1.2. The low deviations between the $T_{\mathrm{s}}$ indicate an equal distribution of BCS in the cross sections.

The results of the $\mathrm{Cr}_{2} \mathrm{O}_{3}$ contents confirm the equal distribution of the BCS in the cross section (Table 6). In this regard, please note the low standard deviations in the layers with a maximum value of 0.1 . In addition, the deviations between the $\mathrm{Cr}_{2} \mathrm{O}_{3}$ contents in the different layers with a maximum value of 0.15 are low. In correlation with the $T_{\mathrm{s}}$, there is a trend that the $\mathrm{Cr}_{2} \mathrm{O}_{3}$ contents in the centre layer are slightly lower compared with the other layers. However, the small deviations are negligible.

The $\mathrm{Cr}_{2} \mathrm{O}_{3}$ contents increase from 2.8 to 4.6 by increasing the use of BCS. However, the increase from a BCS concentration from 4.5 to $5 \mathrm{wt} . \%$ is just 0.1 . The result is in good agreement with the results of the $T_{\mathrm{s}}$. We assume that at a concentration of $4.5 \mathrm{wt} . \%$ the functional groups of the collagen are already saturated and not able to bind more chromium. By increasing the offer of chromium above $4.5 \mathrm{wt} . \%$ in the $\mathrm{CO}_{2}$ tanning process, the share of unfixed chromium increases, leading to high chromium emissions in post-processing.

The results of both studies ( $T_{\mathrm{s}}$ and $\mathrm{Cr}_{2} \mathrm{O}_{3}$ content) show that all skins were well tanned. In contrast to conventional tanning, the $\mathrm{CO}_{2}$ tanning process allows the basification of the tanning solution before the skin absorbs the tanning solution. The accelerated chromium sulphate complexation leads to a time saving of at least $12 \mathrm{~h}$ compared with conventional tanning and basification. We assume that the full penetration with oligo-nuclear complexes is enabled by a swelling of the skin caused by the treatment with pressurized $\mathrm{CO}_{2}$. The dissolved $\mathrm{CO}_{2}$ causes a microscopic swelling in the triple helix of the collagen structure. This effect accelerates the diffusion of the chromium complexes through the collagen matrix (Renner et al. 2012).

In pilot scale, a very equal distribution of the chromium in the cross section was achieved. The improved distribution of the chromium in pilot scale compared to technical-scale results from the bigger diameter of the tanning equipment causing an improved mechanical incorporation of BCS in the skin structure.

\section{Conclusion}

The $\mathrm{CO}_{2}$-intensified tanning process allows the basification of the tanning solution before the formed chromium sulphate complexes have penetrated fully inside the collagen matrix during tanning. The basification of the tanning solution before penetration accelerates the formation of oligonuclear complexes and the collagen stabilization. Compared with conventional tanning and basification, a time saving of at least $12 \mathrm{~h}$ is possible.

The accelerated process does not impair the distribution of chromium oxide in the cross section and the leather quality. However, it is important that high $\mathrm{pH}$ values above 4.5 are avoided during the preparation of the tanning solution. This is achieved by adding the alkali salt in several dosages in fixed intervals. 
In combination with previously reported advantages such as saving about $40 \%$ of tanning agent, avoiding wastewater and minimizing chromium and sulphate emissions, the $\mathrm{CO}_{2}$ tanning process shows a great potential for economical and environmentally friendly leather manufacturing in industrial scale.

Acknowledgements Open Access funding provided by Projekt DEAL.

Open Access This article is licensed under a Creative Commons Attribution 4.0 International License, which permits use, sharing, adaptation, distribution and reproduction in any medium or format, as long as you give appropriate credit to the original author(s) and the source, provide a link to the Creative Commons licence, and indicate if changes were made. The images or other third party material in this article are included in the article's Creative Commons licence, unless indicated otherwise in a credit line to the material. If material is not included in the article's Creative Commons licence and your intended use is not permitted by statutory regulation or exceeds the permitted use, you will need to obtain permission directly from the copyright holder. To view a copy of this licence, visit http://creativecommons.org/licenses/by/4.0/.

\section{References}

Buljan J, Reich G, Ludvijk J (2000) Mass balance in leather processing. https://www.unido.org/sites/default/files/2009-05/Mass_balan ce_in_leather_processing_0.pdf. Accessed 4 May 2020

Covington AD (2009) Tanning chemistry: the science of leather. RSC Publishing, Cambridge

Covington AD, Song L, Suparno O, Koon HDC, Collins MJ (2008) Link-lock: an explanation of the chemical stabilisation of collagen. J Soc Leather Technol Chem 92:1-7

Danylkovych A, Lischuk V, Zhyhotsky O (2017) Structuring of Collagen of the Dermis during Rawhide Formation. ChChT 11:81-91. https://doi.org/10.23939/chcht11.01.081

Faber K (1990) Bibliothek des Leders. Gerbmittel, Gerbung, Nachgerbung, vol 3. Umschau Verlag, Frankfurt am Main

Gamse T (2016) Book of abstracts: ESS-HPT 2016-The European Summer School in High Pressure Technology

Heidemann E (ed) (2005) Leather. Wiley-VCH Verlag GmbH \& Co. $\mathrm{KGaA}$, Weinheim

Imar S, Vernali T (2000) Modeling chromium sulfate complexes in relation to chromium tannage in leather technology: a computational study. Appl Organomet Chem 14:660-669

Indubala S, Ramaswamy D (1973) Separation, characterization and ligand exchange studies of $\mu$-sulphato di-chromium complexes. $\mathrm{J}$ Inorg Nucl Chem 35:2055-2065

\section{Affiliations}

\section{Prokein ${ }^{1}$ (D) $\cdot$ M. Renner ${ }^{1} \cdot$ E. Weidner ${ }^{1,2}$}

1 Material Systems and High-Pressure Technology, Fraunhofer Institute UMSICHT, Osterfelder Str. 3, 46047 Oberhausen, Germany
Moog GE (2016) Der Gerber: Professionelle Lederherstellung, 2., aktualisierte Auflage. Ulmer, Stuttgart (Hohenheim)

Prokein M, Renner M, Weidner E, Heinen T (2017) Low-chromiumand low-sulphate emission leather tanning intensified by compressed carbon dioxide. Clean Technol Environ Policy 19:24552465. https://doi.org/10.1007/s10098-017-1442-x

Renner M (2015) Verfahrensentwicklung zur abwasserfreien Gerbung tierischer Häute unter dem Einfluss verdichteten Kohlendioxids. Dissertation, Karl-Maria Laufen Nachf. Wilhelm R. Kurze

Renner M, Weidner E, Brandin G (2009) High-pressure carbon dioxide tanning. Chem Eng Res Des 87:987-996. https://doi. org/10.1016/j.cherd.2008.12.013

Renner M, Weidner E, Jochems B, Geihsler H (2012) Free of water tanning using $\mathrm{CO}_{2}$ as process additive: an overview on the process development. J Supercrit Fluids 66:291-296. https://doi. org/10.1016/j.supflu.2012.01.007

Rydin S (2011) Global risk-based management of chemical additives 1: risk management of chemicals in leather sector: a case study from Sweden. Springer, Berlin

Sivakumar V, Sundar VJ, Rangasamy T, Muralidharan C, Swaminathan $\mathrm{G}$ (2005) Management of total dissolved solids in tanning process through improved techniques. J Clean Prod 13:699-703. https:// doi.org/10.1016/j.jclepro.2004.01.006

Sundar VJ, Raghava Rao J, Muralidharan C (2002) Cleaner chrome tanning-emerging options. J Clean Prod 10:69-74

Sundar VJ, Muralidharan C, Mandal AB (2013) A novel chrome tanning process for minimization of total dissolved solids and chromium in effluents. J Clean Prod 59:239-244. https://doi. org/10.1016/j.jclepro.2013.07.002

Takenouchi K (1981) Stability of complexes in chromium sulfate solutions and their affinity for collagen. J Am Leather Chem Assoc 76:343-359

Trommer B, Kellert J (1998) Vergleich der verschiedenen Gerbarten auf ihre ökologische Gesamtwirkung, Freiberg. http://v1.filkfreibe rg.de/img/fbleder/Oekobilanz_der_Gerbarten.pdf. Accessed 4 May 2020

Umweltbundesamt (2003) Integrierte Vermeidung und Verminderung der Umweltverschmutzung (IVU): Referenzdokument über die besten verfügbaren Techniken der Lederindustrie, Dessau. http:// www.innochem-online.de/downloads/bvt-merkblaetter/index .html?tx\%E2\%80\%A645. Accessed 4 May 2020

Zissel A (1988) Bibliothek des Leders. Arbeiten der Wassenverkstatt bei der Lederherstellung, vol 2. Umschau Verlag, Frankfurt am Main

Publisher's Note Springer Nature remains neutral with regard to jurisdictional claims in published maps and institutional affiliations.
2 Chair of Process Technology, Ruhr University, Universitätsstr. 150, 44780 Bochum, Germany 